\title{
Naked teaching: uncovering selves in the reflexive classroom
}

\author{
Keith Berry and Nathan Hodges
}

\begin{abstract}
This autoethnography explores our experiences teaching an undergraduate autoethnography course entitled, 'Writing Lives'. We, Keith and Nathan, Professor and Doctoral candidate, convey narrative scenes and reflections of sharing and analysing our published stories with students, working with students through the process of writing their personal stories, and transformative moments during the course. We emphasise a vulnerable, reflexive, and empathetic approach to teaching and learning that allows students and teachers to uncover aspects of who they are and hope to be in the classroom. This work advocates a number of unique benefits to autoethnographic practices that foster open and intimate bonds.
\end{abstract}

We open our end-of-semester course evaluations and read students' comments $^{1}$

This course was difficult, in a fulfilling way. It challenged me to create order out of chaos in my writing and face sensitive emotional experiences head on. Most importantly, the course gave me a safe place to practice reflective writing, which I have never done.

You provided a nurturing and loving environment that allows for students to feel comfortable to tackle vulnerable topics. How you got a class of people who were different ages, nationalities, cultural backgrounds, and belief systems to open up and share their vulnerabilities and insecurities is beyond me.

'Nurturing', 'sensitive emotional experiences', 'vulnerable' - these aren't words typically used to describe college classes. Our students often describe their other classes as sterile, and their relationship with professors and

1 The stories we convey stem from the teaching of two different 'Writing Lives' classes, which we taught separately during the fall 2014 semester. We bring them together here to show a shared orientation to the benefits and challenges inherent to our teaching. 
students as distanced and impersonal. Some students prefer these types of classes, but what happens when professors put their personal guards down and open up about intimate aspects of their lives? Who are we and who do we become as teachers and learners?

This autoethnography explores issues of vulnerability, reflexivity, and empathy among teachers and students. We, Keith and Nathan, Professor and Doctoral candidate, focus on how these issues are lived within 'Writing Lives', a popular undergraduate autoethnography course at our university. First, we provide overviews of autoethnography, relational perspective, and identity negotiation, approaches informing our courses and this article. Next, we include narrative scenes of sharing our stories with students, mentoring students in sharing their stories, and transformational moments. Lastly, we discuss benefits and risks of vulnerability for teachers and students, including how vulnerable teaching allows for a dynamic uncovering of selves. This article advocates teaching as a site for inquiry and joins ongoing discussions about power and identity in teaching relationships (Berry, in press, 2012; Bochner, 2014; Ellis, 2004; Fassett and Warren, 2007; Pelias, 2000; Warren, 2011).

\section{Writing lives}

"You're all here for advanced statistics, right?" I say. Students look back puzzled and shake their heads. "No? Okay, well welcome to Writing Lives. I'm Nathan Hodges and I'm your instructor this semester. You can call me Nathan, Nate, Instructor, or whatever you want as long as it doesn't offend others." Several students laugh. I watch one student scan me from my Chuck Taylor high top shoes to my fedora. I sense his surprise at my casual dress and youth. I look around at the circle of students cramped together in our small classroom. We were originally assigned to a stadium-style seating room, but vulnerable discussion can be difficult when you're looking at the back of someone's head.

"It's important in a class like this that we build an intimate community, so let's get to know each other." We spend the next twenty minutes doing icebreaker activities. Students introduce themselves by saying their name backwards, discussing their writing experience, sharing a 6-word story about 
their lives, and singing a lyric from their favorite song. I participate in the introductions, too.

"Now that you've had a chance to skim each other's surfaces, I think it's important for me to share some history about my life. Each of you this semester will be writing about challenging, personal life experiences and I want you to feel comfortable sharing your personal stories. I'm a third year Ph.D candidate in the Department of Communication and this is my second time teaching Writing Lives. I'm the first person in my immediate family to go to college. My dad is an assembly line worker and my mom is a supervisor in a warehouse, but she spent most of my childhood waitressing. My experiences growing up in a working-class family form the foundation for my graduate studies, and also influence how I approach teaching and writing. I consider myself to be a blue-collar scholar, both working-class and academic. I've made a choice to go to college but I don't in any way see this as a better choice than the choices my family made. You'll get to know more about my history and views on social class throughout the semester, and we will read one of my stories about working in a factory. For now let's go through the syllabus."

Students pull out paper copies of their syllabus. "I'd like you to read through the opening narrative and let me know if you have questions."

I glance down at my copy.

This semester you will write evocative stories about your lives as a way to understand, cope with, and communicate social experiences. Through personal, reflective writing, we learn about ourselves and society, connect to others, come to terms with and reframe experiences, and create new ways of thinking and living. Writing is hard work. To be a better writer you have to write and read a lot. There will be no shortcuts in this class. I believe most deep, meaningful learning is wrought with confusion, doubt, and failure. Trust the process. Jump off the cliff and expect that you'll figure out how to land without turning into soup. When you finally reach ground, you might have a few scrapes and bruises, but you'll have the wisdom and resilience that comes from confronting your vulnerabilities on the page.

A few students get out their cellphone after reading, seemingly uncomfortable. I wave at them to put their phones away. 
"Any questions?" Most students around the room are smiling. A few look scared. "Your major project will be a 15-20 page autoethnography, which will go through several rounds of feedback and revision. What is this long, clunky word, "autoethnography"? Think of autoethnography as personal narrative, reflection, and analysis that weaves in other voices, often from academic literature (Holman Jones, Adams and Ellis, 2013). You will use literary methods - scenes with characters, dialogue, descriptions - to help readers experience an experience, trying to help them see what you saw, feel what you felt, think what you thought, and struggle with the ambiguities and emotional dilemmas you faced. You will also reflect upon and analyse your experience, connecting your personal experience to wider cultural, political, and social experiences. I've created an autoethnography handout for you to use as a reference this semester." I hand twenty-two copies to a student in the front row and ask her to circulate them.

Autoethnography...
is evocative, vulnerable, and reflexive (Ellis, 2004; Berry and Clair, 2011).
aspires to truth, but not certainty. Welcome uncertainty and question yourself
throughout the research process. Autoethnographers realise "truth is contested,
partial, incomplete, and always in motion" (Tullis, Jillian, McRae, Adams and
Vitale, 2009, p.185). We're interested in the potential of narrative truth
(Bochner, 2014), what experiences mean and their utility.
is relational. Autoethnography "is an empathic adventure, a quest to try to see
into the lives of others. . even if such a 'seeing into' is by nature partial, an
interpretive fiction" (Doty, 2005, p.161). Autoethnography is also applied
communication research (Berry and Patti, 2015) that benefits researchers and
others (e.g., readers, audience members).
is critical, allowing us to negotiate socially stigmatized identities and complicate
taken-for-granted assumptions, and to imagine more just, inclusive worlds
(Boylorn and Orbe, 2013).
is a process of inquiry. We learn about ourselves and others through the process
of writing and revising (Richardson, 1994).
can be transformational (Berry, 2013, Ellis, 2009) as we make sense of ourselves
and our experiences through writing. One important therapeutic tool of
autoethnography is narrative reframing (Kiesinger, 2002), in which we "actively
reinvent our accounts. . in ways that empower rather than victimize us" (p. 107).


"Don't worry, we'll discuss these ideas more throughout the semester. Now I want to discuss three words I'll be emphasizing again and again throughout the semester, ideas that are at the heart of the kind of writing and learning community we're working to create this semester." I pull the cap off my dryerase marker and write on the white board:

\section{Vulnerability Reflexivity Empathy}

"As teachers, students, and autoethnographers, I want us striving to be vulnerable, reflexive, and empathetic." I point toward the board. "What's vulnerability?"

"It's opening yourself up," says a male student with long, flowing hair and a soft voice.

"Yes, being vulnerable is like revealing your personal browsing history. A willingness to open up, to stand naked, to reveal doubts, insecurities, and ambivalences, those thoughts and feelings most of us have, but rarely reveal for fear of being stigmatised and rejected."

“And what's reflexivity?" I wait out silence, though a bit longer this time.

"Is it like reflection?"

"Yeah, but a bit deeper. There are different ways of defining and using reflexivity (Berry and Clair, 2011). We each understand the world through the unique vantage point of our lived experience. When you're being reflexive, you're questioning why you think what you think and do what you do, in order to learn from your experiences. You're thinking more carefully about your actions, feelings, and thoughts and how you came to make the decisions you did, including how your experiences are shaped by social, cultural, and political traditions. As autoethnographers we'll practice reflexivity, showing our consciousness on the page, ${ }^{2}$ questioning and arguing with ourselves."

"And what about empathy?"

"Trying to understand another person's perspective."

2 Thanks to Arthur Bochner for this phrase. 
"Yes, empathy involves trying to feel with a person, without judgment, to understand how someone made the choices they did considering the circumstances in which they lived. Good stories involve complex, multifaceted characters. When we set out to blame and vilify, our writing quickly turns into self-righteous narcissism. Without empathy, I see no point in writing."

\section{Uncovering Identity}

"Today we focus on one specific question: "Who am I?" I am leading the students through an introduction to some of the ways in which identity relates to autoethnography.

"As I shared with you during our first class meeting, I use cultural approaches to study relational communication and identity in my research. I am particularly interested in how the societal problem of bullying occurs and impacts youth's lives (see Berry, in press). A 'relational' perspective focuses on the meaning jointly constituted and used between relational partners (Gergen, 2009). Our worlds come alive together. We create and use communication and relationships together."

Students feverishly write down notes, and upon request, I gladly repeat important points.

"Identity, at the very least, refers to who we understand ourselves and others to be. Who am I? I am a relational communication researcher, a student of bullying and identity, an autoethnographer and ethnographer, a gay man, a son and brother, a lover of good dance music, a student of mindfulness, and a best friend."

"What about you ... who are you?"

After a brief pause, several students raise their hands and announce identities: 'college student', 'poor', 'Christian', boyfriend', 'girlfriend', 'manager at work', and 'activist'. 
"Excellent list, and because people embody multiple social locations, I suspect this is only a start to the many identities any one person in here could name about ourselves."

'Identity is 'social,' meaning we come to understand who we are and aren't within our relational communication. Can you think of interactions where this occurs?"

The students name several contexts wherein their identities have been formed, including their families, friendships, romantic partnerships, spiritual groups, and sports teams.

"Yes, good, we form our identities by relating across a diverse range of communication contexts, including this classroom ..."

Students smile noting the link between the concept and our class.

"Also, those identities we have named are only the ones we feel comfortable naming right," Rose says. "What about the ones we didn't tell? After all, I don't know anyone in here."

"Beautiful point. You're talking about the identities we hide, or try to keep from others, an understandable part of our lives. It's often hard for some people to be themselves."

A student in the front row, Justin, whom I have taught in a previous course, and who rarely talks in class, nods his head to affirm my point.

"I want you to begin thinking about how identities are not only formed within interaction and relationships, but are negotiated in those spaces. By emphasising identity as something people negotiate, as a 'give and take' of selves, we study how social constraints inform and sometimes govern who we are, and the challenges and delights that persist in being ourselves (see Berry, in press Yoshino, 2006)."

I notice some students smiling, suggesting they have personal relevance to the concept. 
"We will explore identity throughout the semester, so do not worry if these ideas are new to you. For now, know this: This course, autoethnography, and personal narrative, are informed by the idea that we negotiate stories and identities together."

"Okay, for the rest of the class, let's work on applying these concepts to our everyday lives. In your notes, please answer these fill-in-the-blank prompts with one or two words:

I am

If you really knew me, you would know that I am

The person in my life who has most significantly made me who I am today is

“Once you've answered, find a partner, and share your responses with her/him. You should only write what you're comfortable sharing. Yet, remember we're working to build a space of dialogue in this class, so I hope you'll be as open and honest as you can."

\section{Intimate exposure}

"Good afternoon! Let us begin today's class by discussing my bathhouse piece, Embracing the Catastrophe: Gay Body Seeks Acceptance (Berry, 2007).

In this piece I use personal narrative to examine issues concerning idealised body types among gay men. I draw on moments from my lived experience in a gay bathhouse, a cultural site for sexual activity and socialising. I focus primarily on standards used by many men in their interactive process of naming certain bodies attractive and acceptable. The essay is an example of autoethnography and personal narrative, one of many different models you may consider for your project."

Many students nod their heads. Others' eyes are now wide open, perhaps because I've mentioned gay sex. 
"I wrote this piece because I believe people negotiate identities within diverse contexts, and the bathhouse site has often been overlooked by 'traditional' research. Writing this essay exposes the context, and in doing so, I expose myself to readers."

"Funny," Morgan says smiling. Several students chuckle, some grimace, letting me know they recognise my double entendre.

"My word choice is meant to be both humorous and meaningful. By publishing this piece and making it assigned reading, I am making myself vulnerable. I am taking risks in terms of how readers will understand and react to me. How will readers evaluate this work? Will they accept the 'me' I locate on the page? Might they reject my ideas, thereby rejecting me?"

"This type of writing is personal on purpose," Morgan adds.

"Yes, and I am your professor, a role that makes this personal work more vulnerable. How many of your professors open themselves up in this way? It is fine if they do not, and sometimes it is not appropriate given their subject matter. It is not uncommon in my experience to hear people suggest that teachers and students can be close, but not too close. Exposing myself in these ways troubles common assumptions about boundaries."

Some students nod their heads and write in their notebooks. Many have the glazed look on their faces that comes from too much abstract thinking. Time to move on to the story.

"What did you think of my essay?"

Justin breaks the silence, "I don't know if I can expose myself like this. I think it is brave to share stories like yours. I mean, I do not have anything to hide, but don't think I can be so vulnerable."

A few students nod their heads.

"Your concern is perfectly understandable. This process involves putting ourselves on the line and the outcome is rarely known in advance. It can be scary. In this course you only write about experiences, thoughts, and feelings which you feel comfortable sharing." 
"I think this story is amazing and I learned a lot from it," Rose adds.

“Thank you. What specifically was helpful?"

"For me it is the way you use vivid details about the bathhouse and being there, somewhere I have never been, and how isolated and on display this place makes you feel. There is one moment in the piece ... well, let me read it out loud." She flips through the article:

I recheck my towel, tighten its grip, and continue roaming through the various corridors on this floor. I walk passed the private rooms, peer inside, and typically see one man in each. ... Standing in front of these doors, which remain open as instances of overt sexual advertisement, I extend up and down glances of my own, often provide a smile, raise one of my eyebrows, grab and rub myself in the crotch, and work to make some form of connection. (Berry, 2007, p.272)

I smile hearing her read my words. Many students have marked this passage as being significant to them when I used the essay in past classes. I also smile because this is the passage about which I feel the most vulnerable. I, their professor, am openly sharing details about fondling myself in front of strangers. Thus, I smile in part from the awkwardness of this moment awkward not because I feel the moment is 'wrong', but because this exposure makes me so vulnerable.

She continues reading:

[My] connection attempts can be futile and deceiving; so many of these men want to be penetrated, and perceived health risk keeps me from delivering . . I am more often greeted with an uncompromising "no" gesture with the head, perhaps a swift hand and arm gesture telling me to move on, or worse yet, the other-from his bed-kicks the door shut. .. Coldness can become frequent in the baths (Berry, pp.272-273).

"Thank you for performing my words so beautifully," I say joining students in applause.

Her performance enlivens many students. Some sit forward in their seats and appear to be looking for other passages to discuss. Yet others look disengaged, fidgeting with their cell phones and doodling in their notebooks. It is difficult to ignore the disengaged. Did they not read? Are they silent because they disapprove of bathhouses? Of someone being gay? I work to let go of needing to know, but their silences stay with me. 
“So why does this passage stay with you?" I ask.

"Honestly, the story makes me think differently about you. I think so many of us are not used to knowing this much about our teachers. Our teachers care and are involved in our learning, but we don't really know them. We don't read about them being rejected by having a door slammed in their faces. We're really getting to know you."

"I love that you see it in that way," I say.

"It's not wrong, just different. But I still don't feel as though I can be so vulnerable," Justin says.

"That's fine. Although I will be asking you to learn in ways that will probably challenge your comfort zones, you should be yourselves however it is you bring your story to life. Also, just because my experience writing like this has allowed me to be more comfortable with, and even excited by, vulnerability, that doesn't mean I don't still get nervous. Think about it - I'm standing in front of twenty five students who read about me in a bathhouse. I was a little nervous coming in today."

"The nerves don't go away?"

"The process often gets better over time and with practice. Yet, I think some nervousness is healthy. Maybe we're nervous because the things we're talking about matter so much to us, and we're unsure how others will respond. I've learned to become more at peace with the nerves."

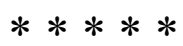

"Before we begin our discussion, please get out your copy of the article and your body part story." Students get out their paper copies of my article, The American Dental Dream (Hodges, 2015), and their writing assignment - a personal story about a body part. I scan my first page while waiting:

The cultural desire for straight, white teeth - is difficult, if not impossible, for poor and working-class people to achieve. In this autoethnography, I brush away the taken-for-granted assumptions about teeth, exploring the personal, relational, and structural consequences of this cultural desire, and showing how social class writes itself on our bodies. I write these teeth tales to show how one might cope with their teeth (Hodges, p.943). 
"I share my autoethnography with you, not only as a model for your own paper, but to show you I am also a human being with personal struggles and insecurities. I'd be interested in hearing your connections, stories, questions, criticisms, grade-boosting praise." Several students laugh. "What'd you all think?"

"I really like it," Jessica says.

"Thanks. What'd you like about it?"

"I related to it. I grew up with messed up teeth, and I was always so embarrassed by them. I wouldn't smile in photos or talk in class. It seemed all my friends had perfect teeth. But my parents couldn't afford braces. Once I finally had the money I fixed my teeth." I wince at her use of 'perfect' and 'fixed' teeth, implying her teeth were a problem, instead of the problem being the idea of perfect teeth, but I stay quiet and let her story be.

"I saw myself in the story, too," Heather adds. "I hadn't realised how little I thought about teeth until I read the article, but you're right - our teeth are connected to our social class and we make class judgments about people based on their teeth. Even I do."

"I worked at a dentist's office for seven years and this American Dental Dream is real," Anna adds. "We're so obsessed with these perfect movie star teeth. I remember how patients would tear up with joy when they saw their dental transformation for the first time."

"Thank you all for sharing your connections," I say. "I believe this idea of 'perfect teeth' several of you alluded to is an illusion. The idea of which teeth are desirable, perfect, or normal, is a cultural ideal. It's not inevitable and could be otherwise. Yet, this cultural desire is powerful. How many people in here have had braces?"

All but two students raise their hands. "And how many of you are completely happy with your teeth?" No one raises their hands. "So braces didn't solve the insecurities with your teeth. You are led to believe your teeth need fixed, and can look better. This deficit discourse (Gergen, 1994) is what keeps the capitalist engine running. We create problems needing 'fixed' by introducing new products and services. Just think about how the introduction of whitening strips and braces changed how we understand teeth." 
"After reading your article I went and immediately whitened my teeth," says Melissa. "I know this is the opposite of what you hoped but the pressure never seems to end."

"I hate to be the outlier here but I have straight, white teeth and I've never had any orthodontics," one of my favorite students, Dustin, responds. "This seems to be a sweeping generalisation. I don't really see the connection between social class and teeth."

"Well I do say in the article that straight, white teeth that meet the cultural ideal requires good genetics or a lot of money. However, many people have some sort of dental intervention. Look at how many people have had braces in here."

“That's why I think your story is relatable," says Josh. "I had braces but I still have insecurities about my teeth even after my parents spent thousands of dollars on them."

"Many of us have these minor bodily insecurities (Ellis, 1998) we rarely talk about and we each find our own ways of coping with them," I say. "When we share our stories with others we can feel a little less alone in these insecurities."

"I felt that connection reading your article," says Tara. "I had horrible acne in high school and we weren't allowed to wear makeup in my school. I was so embarrassed. I felt like all anyone could see was my acne. It's like how your mom described her teeth in the article."

"I felt the same way about my ears," Derron adds. "They're so big and kids used to make fun of me, calling me 'Dumbo', like the elephant. But then when I found out how to wiggle them, everyone wanted to see my tricks."

"No way," Ian says. "Show us!" We laugh as he wiggles his ears up and down.

"That's great you found a way to reframe something you were embarrassed by into something you embrace and makes you unique," I say.

"I related too," Natalie says. The bridge of my nose is pronounced and every time I'm around my grandma she makes comments about it. She even offers 
to pay for plastic surgery to get it fixed." Several students gasp. "But I've grown to love it. It holds my glasses up nicely," she says grabbing her frames. Several students laugh.

"People make judgments about my nose," Lance adds. "People say I have a Jewish nose. I identify as Christian but my dad is Jewish, and I felt in some ways this was an attack on him."

"I really connected," says Lacey. "I have a slight eye misalignment called pseudostrabismus." Basically my left eye is about two degrees off from my right, making me appear cross-eyed. After reading your story, I realised my eye affects my life in ways I wasn't aware of, like realising I don't have any selfies online because it's most noticeable in pictures. Now I want to write my autoethnography about my pseudostrabismus, though a part of me feels it's a minor problem and writing a 20-page paper about it is blowing it out of proportion."

As she talks, I realise I'm staring at her eyes and look down at my article instead.

"Wow, thank you so much for sharing," I say. "Your comment reminds me about the double binds of discussing minor bodily stigmas. For example, many of you may have never even noticed my teeth before reading this essay, but I'm guessing many of you tried to get a peek at them today." The class laughs, my humour resonating. "Other responses?"

"I admire how you used humour to cope with your teeth. Like how you named your snaggletooth and snarled it at people," Erick says. The class laughs. "I also admire your honesty, like how you write about stealing whitening strips from Wal-Mart."

"Yes, your teacher has broken the law," I joke nervously. "Most stores now have them locked behind glass cases because so many people were stealing them."

"This discussion has made me realise we all have something we're insecure about and afraid to talk about it, making that insecurity even more powerful in our minds," Erick says.

"Yes, and I hope my openness inspired you to be open with your own stories." 
Hands shoot up in the air. "Your story made me think about...

“... the moles on my arms."

“. . being a woman with 'man hands'.”

“... the stretch marks on my boobs."

"... the gap between my front teeth."

“. . the scar on my lip."

“. . being a black woman with "natural' hair."

“. . my skinny legs."

“. . my obesity and how I use humour to hide my insecurity."

“.. . being a short man."

“. . my bowleggedness.”

The stories pour out.

\section{How much to reveal?}

"So what are you thinking of writing your final paper about?" I ask Rochelle, who shifts in her seat. I meet with each student individually to discuss their autoethnography. In these meetings students share personal stories and we talk through ideas, discussing potential ethical issues, and figuring out what they hope to get out of the writing process.

"I have a few ideas but the one I think I have the most to write about is my relationship with my mom," she says. I nod my head, encouraging her to continue. "She's crazy."

"What do you mean by crazy?" 
"She's literally crazy. Like she cheated on my dad and completely destroyed our family. Now she drinks all the time and goes out to the bar with all these trashy guys. I figured I have a lot I could write about."

"Okay, I just want to say before you carry forward with this project that I will be pushing you to consider your mom's perspective, not to justify her actions, but to hopefully understand more about how she made those choices. Part of what we're trying to do in this class is to write about experiences we haven't quite figured out yet as a way to better understand, come to terms with, and cope with them. You seem pretty angry at your mom right now. But writing a story that only blames and vilifies doesn't allow you or others to learn from the experience. I just want you to know that if you stick with this topic, I will be asking you to write through the anger and practice moving toward empathy."

She nods her head. "I understand. Like I know she married my dad when she was really young and got pregnant. She's said before that she didn't get to experience those party years during her youth because she was a mom and a wife. That could be part of it."

"That's a good start."

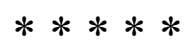

"You've done some promising work on your final project proposals, and I am thrilled by the plans for your stories. The topics you chose are deep and important - grief from death of a loved one, body image issues, family conflict, racism and homophobia, just for starters. I know you'll be proud of the work you create." Smiles beam across several faces. Many were nervous when talking with me about their topic. This class represents the first time many have been asked to talk so honestly and deeply about themselves.

“That's a big statement,"Maria says.

"It feels truthful to me," I add. "Reflexively writing and telling our stories is often emotionally taxing, because the process asks us to relive past experiences, some of which are difficult and maybe even traumatic. We then resist the human temptation to cover up intimate details, and decide instead to openly share information, baring our selves. There is no secret antidote for 
doing this work, and storytelling is certainly not a panacea that miraculously fixes our lives."

Students giggle, noting my flair for the dramatic.

"Your proposals also show me more of you are becoming comfortable with writing about personal, intimate details of your life."

"What I am unsure of is how to do it, or actually, how far to go," Alberto responds.

"I appreciate and respect your concern. The smiles and head nods from your fellow students tell me you are not alone. They also tell me today's in-class workshop focusing on self-disclosure and personal narrative is an important next step."

I distribute to each student one half-sheet of paper showing part of a personal story I wrote about bullying. Wanting to not discourage them from being honest, I do not tell them I am the storyteller.

"Please read through and reflect on this passage. As you move through the paragraph, pay attention to what you learn about the author."

Students read through the following passage:

Noman smiles and nods "hello" as he sees me walking up to him during recess. He is a short Pakistani boy who usually keeps to himself at school. On this winter day, my eyes are fixed on his coat - a long, thick and puffy winter coat, bigger than any one I have ever seen. "Nice coat," I say sarcastically, as I poke at his chest, by his heart, feeling the sharpness of my fingers attempts to penetrate the puffiness. Nearly inaudible, he mumbles back, "(Something, I think, about) cold and (something about) snow." My pokes continue, and I yell, "I cannot hear you, NO-MAN, talk louder!" He acquiesces to my aggression, his body goes limp, and he evades eye contact with me by staring at the ground. Still not satisfied, I grab Noman by his coat, my boy fingers barely able to cling onto his puffed up coating, and pushed him against the brick wall. "Owwww," he says. His eyes are shut, seemingly to prepare for more roughness. 
“Okay, what do you think?” I ask after five minutes pass.

"I think the author is honest," Alberto says.

"Honest?" Rose interrupts. "What is honest about this passage?"

"Well, the author is honest about bullying Noman. There are no excuses."

"Fine," Rose replies, "But we learn nothing in the passage about reasons why the author bullied Noman. We also don't know what type of relationship they had. Were they friends? Strangers? Knowing this information would help me know how I feel about the violence."

"Sounds like you want to know more about what informed this relational exchange, which is important. Here's another question: what do we know about how the author felt, or what the author's thought process was related to this episode?"

"We know very little about that, except for what we might guess."

"Right, we know the author attacked Noman, but we don't know how he - I am assuming it's a boy - felt before, during, or after. He's a kid, attacking an innocent peer at school, someone smaller and weaker than him. Did that make him feel stronger? Did he regret the violence? I suspect some of those thoughts and feelings are not pretty, and they can lead the author to feel bad about his actions, or shame. But I want to know more from and about the storyteller."

"Why would we want to know more about these things?"

Multiple students' raise their hands.

"Wow, a lot of folks have something to say. This is great. Let's just list off the reasons you have in mind. So, fill in the blank: "By knowing more intimate details, I will ..."

... know what or how I should think or feel about the violence. For example, the situation feels different if he has no concern about his harmful actions. 
... be able to compare it to my own experiences with bullying.

... understand more about conflicts similar to the one portrayed in the story.

"Fine work, you explored this so mindfully," I say. "Now let me help you think about these issues in even more specific ways, which I believe will help you in writing your stories." A few students grab their pens, readying themselves to take notes.

"Your reasons speak to the importance in autoethnographic storytelling of working to be transparent; of 'thickly' describing the lived experience we convey; and of disclosing enough for readers to have a clear and meaningful sense of what it is like to live and negotiate these relational realities and identities (Ellis, 2004). Overall, it seems, to me, like you want to be drawn in closer to the stories and the storytellers ... to know both better."

"You make us sound smart," Alberto says.

"You are smart, and you can write smartly in these ways. It just takes time and practice." By the way, I am the author of that passage. Noman and I were friends, and I felt terrible about committing such violence!"

A few students gasp at my revelation.

"I didn't tell you because I didn't think you would give all this criticism if you knew I was the author. By covering myself, I figured you might feel more comfortable saying tough things. Maybe I should have trusted you and revealed my part in this to you before reading."

The students respond with a range of playful comments: "You got us!" "Very sneaky. .." and "Glad I didn't say what I was really thinking about the bully!"

\section{Naked emergence}

"I am going to miss this class." These words come from Sophia, a student who has not said much this semester. Her speaking up now feels significant. She continues, "I feel weird announcing this, but I will miss the people in here." 
The class responds with, "awwwwww" and "that's so sweet".

"The class has been a very unique experience for me, and I think that has to do with more than just learning about autoethnography. I think it has something to do with how close many of us have become to one another, and who we've become together as a result of sharing some heartbreaking stories."

More students nod their heads, though a few others doodle in their notebooks, evading my eye contact. I don't know their reasons for being disengaged. Yet, their response is a reminder not all students will experience vulnerability in positive ways. Many uncover less for any number of reasons, including self-protection.

"Personally, I love what we have created this semester. I cannot remember one class in all of my years of teaching where students have without prompting begun reflecting on the foregoing semester weeks before the class ends. But this shouldn't surprise us. As I mentioned when we embarked on this journey together, by investing in the course, doing the necessary work, taking risks, and being there for each other, something special would likely form. It has been an honor to work with you."

"Well, thank you for being our fearless, towel-wearing leader," Rose says dramatically but sincerely.

"You're welcome, and thank you, you all led - each other, and me - in your own ways. That leadership has resulted in what has become a wonderfully supportive community of storytellers. Also, it's been amazing to see many of you become more open, confident, and creative writers. You, too, have exposed yourselves and lived to tell about it!"

"I think I am going to cry. Are we supposed to cry in classes?" Sue asks.

"Sure. I should have known to bring a Kleenex box to an autoethnography class. Thank you all for what you have given me. I have grown as a result of our reflexive and vulnerable learning this semester."

"You have grown, how so?” Alberto asks. Several others look confused.

"Yes, many teachers are impacted by teaching, too. As you know I am writing 
my book, an autoethnographic examination of bullying, youth, and identity, which includes my reflexive stories of bullying from my youth". (Berry, in press)

"So what was our help?"

"Since it has been over thirty-five years since I was a youth, at times I have found it difficult to identify 'my bullying story'. By witnessing you take risks in writing and classroom discussion by reflecting on difficult experiences of hardship and suffering, I was moved to look more deeply into my bullying past. I heard myself encouraging you, and began to follow my own advice. I began to explore my past more gently and imaginatively. Your vulnerability and willingness to tell your stories, stories that matter, encouraged me to stay with my own process and to identify what stories from back then still matter today."

"Wow, we did all that?"

"You did, and perhaps without even knowing it. That's the power possible from relating with others in open ways. As I helped you, you helped me see my story in different ways. I am grateful to you for pushing me deeper into my story."

\section{Stripping down}

We sit beside each other looking at the same computer screen.

"How do we end? What does naked teaching do for teachers and students?"

"I think we become more relatable. Rather than being detached authority figures, we are teachers who have personal struggles and identify with students' struggles. Also, through personal writing, students are challenged to explore how their education personally impacts their lives. This isn't abstract knowledge. This is their life they are writing about. This vulnerable teaching style also allows for multiple selves to be experimented with, performed, revealed and concealed."

"There are also risks to this kind of vulnerability." 
"Yes, the selves performed within this space aren't always desired or affirming. We're often working through some distressing issues. Yet, the aim is to be ourselves and try to help people better our lives. Whoever we become through the process, we convey the joys and sorrows of our stories together."

"We've also both had experiences with students that made us realise the risks and limits of vulnerability. For example, I taught a veteran student who never once spoke about his time in the military throughout the semester. During our early semester meeting about his paper he told me talking about these combat experiences in a room full of strangers was impossible, that he could barely discuss them with family and close friends. Yet he wrote and revised his autoethnography throughout the semester, at first only sharing his paper with another veteran in the class but eventually he presented his story to the whole class."

"Others have worked on stories about deeply traumatic experiences, including homophobia, self-mutilation, and rape. Several rape survivors have shared their stories for the first time in my class. Many wrote brilliant stories yet could not speak one word about their experience to anyone, let alone deliver a final presentation to the class about their stories. While some critics might say 'true success' in this teaching should require students to be fully open, we don't envision naked teaching that way. Honoring these individuals means meeting students where they are. Sometimes a one-on-one presentation between student and professor suffices, or sometimes submission of the paper itself is enough."

"The outcomes aren't always distressing. My students helped me find my bullying story."

"And the most unexpected, affirming experience I had was when a student attached a letter to her paper telling me she loved when I spoke about how being an academic makes me no better than my working-class parents. She said that resonated deeply with her and she now holds that opinion too. This has made me realise how important it is to be my working-class self in the classroom."

"The value of these stories extends beyond Writing Lives and other life writing courses. Shouldn't any educator consider issues of vulnerability, reflexivity, and empathy in their classrooms, even in courses that don't explore deeply personal issues? Of course what that vulnerability means and 
how it is performed is contingent on the given context, like what the course is and who the storytellers are."

"Are you seeing the parallels between autoethnography and the teaching we advocate? In each, issues of vulnerability, reflexivity, and empathy are vital. Autoethnography is more than a writing method."

"It's an orientation to the world. It's a way of life" (Bochner, 2014).

"Autoethnography offers educators a more personal, humane approach to teaching and learning, putting students and teachers lives at the forefront of their education."

"Autoethnography does more. It is not uncommon today to hear stories about lazy and indifferent students, or a lack of passion in higher education. In Writing Lives we saw passionate, hard-working students who opened themselves up in ways that allowed themselves and others to grow."

"Sounds like we've found an ending. Let's start writing."

\section{References}

Berry, K. 2007. Embracing the catastrophe: gay body seeks acceptance. Qualitative Inquiry, 13: pp.259-281.

Berry, K. 2012. (Un)covering the gay interculturalist. In Bardhan, N. and Orbe, M.P. (Eds), Identity research and communication: intercultural reflections and future directions. Lanham, MD: Lexington Books, pp.223-237.

Berry, K. 2013. Spinning autoethnographic reflexivity, cultural critique and negotiating selves. In Holman Jones, S., Adams, T.E. and Ellis, C. (Eds.), Handbook of autoethnography. Walnut Grove, CA: Left Coast Press, pp.209-227.

Berry, K. and Clair, R.P. 2011. Contestation and opportunity in reflexivity: an introduction. Cultural Studies - Critical Methodologies, 11: pp.95-97. 
Berry, K. (in press). Bullied: tales of torment, identity, and youth. Walnut Creek, CA: Left Coast Press.

Berry, K. and Patti, C.J. 2015. Lost in narration: applying autoethnography. Journal of Applied Communication Research, 43: pp.263-268.

Bochner, A. 2014. Coming to narrative: a personal history of paradigm change in the human sciences. Walnut Creek, CA: Left Coast Press.

Boylorn, R. and Orbe, M. (Eds). 2013. Critical autoethnography: intersecting cultural identities in everyday life. Walnut Creek, CA: Left Coast Press.

Doty, M. 2005. Return to sender: memory, betrayal, and memoir. In Williford, L. and Martone, M. (Eds), Touchstone anthology of contemporary creative nonfiction: work from 1970 to present. New York, NY: Simon and Schuster, pp.152-164.

Ellis, C. 1998. "I hate my voice": coming to terms with minor bodily stigmas. The Sociological Quarterly, 39: pp.517-537.

Ellis, C. 2004. The ethnographic I: a methodological novel about autoethnography. Walnut Creek, CA: AltaMira Press.

Ellis, C. 2009. Revision: autoethnographic reflections on life and work. Walnut Creek, CA: Left Coast Press.

Fassett, D.L. and Warren, J.T. 2007. Critical communication pedagogy. Thousand Oaks, CA: Sage.

Gergen, K. 1994. Realities and relationships: soundings in social constructionism. Cambridge, MA: Harvard University Press.

Gergen, K.J. 2009. Relational being: beyond self and community. New York: Oxford. Cambridge: Harvard University Press.

Hodges, N. 2015. The American dental dream. Health Communication, 30: pp.943-950.

Holman Jones, S., Adams, T.E. and Ellis, C. 2013. Handbook of autoethnography. Walnut Grove, CA: Left Coast Press. 
Kiesinger, C. 2002. My father's shoes: the therapeutic value of narrative reframing. In Bochner, A. and Ellis, C. (Eds). Ethnographically speaking: autoethnography, literature, and aesthetics. Walnut Creek, CA: Altamira Press, pp.95-114.

Pelias, R.J. 2000. The critical life. Communication Education, 49: pp.220-228.

Richardson, L. 1994. Writing: a method of inquiry. In Denzin, N. and Lincoln, Y. (Eds). Handbook of Qualitative Research. Thousand Oaks, CA: Sage, pp.516-529.

Tullis, O., Jillian, A., McRae, C., Adams, T.E., Vitale, A. 2009. Truth troubles. Qualitative Inquiry, 15: pp.178-200.

Warren, J.T. 2011. Reflexive teaching: toward critical autoethnographic practices of/in/on pedagogy. Cultural Studies - Critical Methodologies, 11: pp.139-144.

Yoshino, K. 2006. Covering: the hidden assault on our civil rights. NY: Random House.

Keith Berry

Nathan Hodges

Department of Communication

University of South Florida

keithberry@,usf.edu

nlhodges@mail.usf.educ 